\title{
Evaluasi Spektrum Gelombang USG Doppler dan Kaitannya dengan Ankle Brachial Index (ABI) dan Faktor-Faktor Risiko pada pasien Peripheral Arterial Disease (PAD)
}

\author{
Patrianef Darwis $^{1}$, Faisal Ali Ahmad Kler ${ }^{1}$, Karina $^{1}$, Rizky Saputra Telaumbanua ${ }^{1}$ \\ ${ }^{1}$ Divisi Vaskular dan Endovaskular, Departemen Bedah, Fakultas Kedokteran Universitas \\ Indonesia, Rumah Sakit Cipto Mangunkusumo
}

\begin{abstract}
Abstrak
Latar Belakang. Salah satu komplikasi dari Peripheral Arterial Disease (PAD) adalah kerusakan tungkai bawah hingga tidak dapat digunakan untuk beraktifitas. Skrining dan penegakan diagnosis lebih awal diharapkan memberikan outcome yang lebih baik.

Metode. Penelitian studi potong lintang pada pasien PAD di Rumah Sakit Cipto Mangunkusumo dari Juli 2013-Desember 2014. Terdapat 119 pasien yang sesuai dengan kriteria inklusi. Analisis univariat dilakukan untuk memperoleh gambaran distribusi frekuensi masing-masing variabel bebas dan analisis bivariat untuk menilai hubungan antara variabel terikat. Uji Mann Whitney dilakukan untuk menganalisa hubungan antara spektrum gelombang DUS dan ABI pada pasien PAD.
\end{abstract}

Hasil. Didapatkan pasien PAD dengan nilai ABI rata-rata 0,7 dengan gambaran gelombang DUS yang berubah dari trifasik menjadi non-trifasik dominan pada arteri infrapopliteal. ABI di bawah 0.9 menunjukkan perubahan pada gelombang DUS dari arteri femoralis hingga a.dorsalis pedis dengan nilai $\mathrm{p}<0.05$. Faktor risiko yang signifikan pada PAD adalah usia di atas 45 tahun. Terdapat hubungan signifikan dengan $\mathrm{p}<0,05$ pada hubungan antara gelombang DUS, ABI dan beberapa faktor risiko PAD.

Kesimpulan. Derajat keparahan PAD dapat ditentukan melalui nilai ABI dan DUS. Letak oklusi pada segmen arteri dapat diketahui dengan gelombang DUS. Penilaian ABI dan DUS memiliki hubungan positif terhadap faktor risiko PAD.

Kata kunci: Peripheral Arterial Disease, Ankle Brachial Index, Spektrum USG Doppler, Faktor-Faktor Risiko PAD (ISSN 2723-7494 J Bedah Indonesia. 2020;48:68-85) 


\section{ARTIKEL PENELITIAN}

\section{Korespondensi penulis:}

Patrianef Darwis

Divisi Bedah Vaskular dan Endovaskular. Departemen Ilmu Bedah Fakultas Kedokteran Universitas Indonesia Rumah Sakit Cipto Mangunkusumo

email : patrianef@gmail.com

ORCID ID

https://orcid.org/0000-0002-4982-9034 


\section{ARTIKEL PENELITIAN}

\section{Pendahuluan}

\section{Peripheral Arterial Disease (PAD)} merupakan suatu kelainan progresif yang menjadi penyebab paling sering hilangnya kemampuan untuk berjalan akibat iskemia tungkai kronis. ${ }^{1}$ Berdasarkan Guideline PAD 2019 diketahui bahwa ada sekitar > 202 juta orang yang menderita PAD di dunia. $^{2}$ Jun Shu (2018) mengatakan populasi yang berisiko tinggi menderita PAD adalah yang berusia lanjut, dengan prevalensi 29\% pada kelompok individu usia $>70$ tahun tanpa faktor risiko lain atau 50-69 tahun dengan riwayat merokok atau diabetes melitus. ${ }^{3}$

Prosedur diagnostik efektif dan teknologi yang memiliki nilai prognostik sangat diperlukan dalam upaya deteksi dini dan pengobatan untuk menghindari komplikasi dan intervensi. Para ahli saat ini menggunakan kombinasi dari anklebrachial Index (ABI) dan analisis gelombang Doppler Ultrasonography (DUS). ${ }^{4}$ ABI merupakan alat skrining noninvasive non-imaging yang paling baik untuk mengevaluasi keberadaan penyakit arterial pada ektremitas bawah. ${ }^{5,6} \mathrm{ABI} \leq 0.9$ merupakan penilaian awal untuk menegakkan diagnosis PAD. ${ }^{2,5,6}$ DUS merupakan alat yang non-invasif untuk visualisasi arterial di ekstremitas bawah. ${ }^{7,8}$

\section{Metode}

Penelitian ini bersifat potong lintang yang dilakukan pada April Juli 2015 di Divisi Bedah Vaskular Departemen Ilmu Bedah FKUIRSCM, Jakarta. Populasi pada penelitian ini adalah semua pasien yang terdiagnosis PAD dan telah dilakukan pemeriksaan Doppler USG di Divisi Bedah Vaskular RSCM pada kurun waktu Juli 2013 sampai Desember 2014.

Pengambilan sampel dilakukan dengan konsekutif yaitu menggunakan seluruh pasien yang terdata dalam data rekam medis Divisi Bedah Vaskular yang memenuhi kriteria inklusi dan eksklusi. Kriteria inklusi pada penelitian ini adalah pasien PAD yang berobat ke Divisi Vaskular dan Endovaskular Departemen Ilmu Bedah FKUI-RSCM periode Juli 2013 sampai Desember 2014, menjalani pemeriksaan Doppler USG, ABI $\leq 0,9$, dengan kriteria eksklusi PAD NonAtherosklerotik seperti disebabkan oleh Vaskulitis dan Buerger Disease. Variabel 


\section{ARTIKEL PENELITIAN}

bebas dalam penelitian ini adalah usia, jenis kelamin, merokok, hipertensi, hiperlipidemia, diabetes melitus, riwayat CAD dan CVD.Variabel terikat adalah pasien PAD yang menjalani Doppler USG dengan $\mathrm{ABI} \leq 0,9$. Data yang telah dikumpulkan melalui pengumpulan data sekunder dilakukan verifikasi dan diolah menggunakan program statistik SPSS ver 20.0 for windows. Uji analitik yang dilakukan adalah Uji Man Whitney untuk menilai hubungan antara ABI dan faktor risiko pada pasien $\mathrm{PAD}$, dan Uji statistik yang dilakukan adalah Uji Chi Square untuk menilai hubungan antara spektrum gelombang DUS dengan faktor risiko PAD. Penelitian ini telah disetujui Komisi Etik Penelitian FKUI nomor 464/UN2.F1/ETIK/PPM.00.02/2019.

\section{Hasil}

Data diambil dari bulan Juli 2013 hingga bulan Desember 2014 dan diperoleh sebanyak 199 pasien dengan PAD. Sebanyak 80 data pasien tidak dapat dianalisis karena tidak termasuk kriteria inklusi dan data yang tidak lengkap. 119 pasien yang diperoleh data sesuai dengan nilai tertingginya 0,9 . Sedangkan untuk segmen arteri poplitea, didapatkan gelombang monofasik dengan nilai median penelitian ini. Data diperoleh dengan cara pengambilan data melalui rekam medis dengan pemeriksaan $\mathrm{ABI}$ menggunakan handheld Doppler dilanjutkan pemeriksaan menggunakan DUS pada sampel pasien PAD Divisi Bedah Vaskular dan Endovaskular di RSCM.

\section{Karakteristik Spektrum Gelombang USG Doppler pada pasien PAD}

Pada (tabel 1), gambaran spektrum DUS berupa gelombang trifasik, bifasik dan monofasik di segmen arteri femoralis pada 119 pasien $\mathrm{PAD}$, dengan gambaran gelombang trifasik sebanyak 73 pasien yaitu $61,3 \%$, gambaran gelombang bifasik sebanyak 46 pasien yaitu $38,7 \%$ dan tidak ada pasien dengan gambaran gelombang monofasik.

\section{Hubungan antara ABI dan Spektrum USG Doppler}

Pada (tabel 3) terdapat hubungan signifikan antara ABI dan spektrum gelombang DUS pada semua segmen dari arteri femoralis hingga arteri dorsalis pedis dengan $\mathrm{p}<0,05$. Pada arteri femoralis didapatkan gelombang bifasik dengan nilai ABI 0,60 dimana nilai terendahnya 0,4 dan ABI 0,6. Pada arteri tibialis posterior, gelombang monofasik tampak pada nilai median ABI 0,7, nilai terendahnya 0,5 dan 


\section{ARTIKEL PENELITIAN}

tertingginya 0,9 . dan pada arteri dorsalis pedis, gelombang monofasik juga tampak pada nilai median $\mathrm{ABI} 0,7$ dengan nilai terendahnya 0,4 dan tertingginya 0,9 .

\section{Hubungan antara ABI dan Faktor- faktor Risiko pada pasien PAD}

Pada (tabel 4) ditemukan variabel usia, hiperlipidemia dan DM mempunyai nilai $\mathrm{p}$ yang signifikan. Terlihat bahwa adanya hubungan signifikan antara peningkatan usia dengan penurunan nilai ABI. Usia $\geq 45$ th mempunyai nilai median ABI 0,7 dengan nilai $\mathrm{p}=0,001(\mathrm{p}<0,05)$. Sementara itu, tidak terdapat hubungan signifikan antara jenis kelamin, merokok, hipertensi, riwayat CAD dan CVD dengan nilai ABI $(p>0,05)$. Pada kasus hiperlipidemia (peningkatan kadar LDL darah), penurunan $\mathrm{ABI} \leq 0,9$ mempunyai hubungan signifikan dengan peningkatan LDL darah dengan nilai $p=0,010(p<0,05)$. Pada pasien diabetes melitus secara statistik juga memiliki hubungan signifikan antara penurunan nilai ABI dengan penyakit diabetes melitus yaitu dengan nilai $\mathrm{p}=$ $0,037$ ( $\mathrm{p}<0,05)$. Pada pasien diabetes melitus nilai rata-rata ABI 0,69 dengan nilai terendah 0,4 dan tertingginya 0,87 . Sedangkan yang tidak mengalami diabetes melitus mempunyai nilai median ABI 0,73 dengan nilai terendah 0,6 dan tertingginya 0,9 .

Hubungan antara Spektrum USG Doppler dengan Faktor-faktor risiko

Pada (tabel 5) terlihat hubungan antara spektrum gelombang DUS pada segmen arteri femoralis hingga arteri dorsalis pedis dengan faktor-faktor risiko hanya terdapat hubungan signifikan antara usia di atas 45 tahun dengan gelombang DUS yaitu $\mathrm{p}<0,05$.

Pada (tabel 6), tampak pada arteri poplitea terdapat jumlah pasien yang banyak dengan gelombang bifasik yang mempunyai usia diatas 45 tahun yaitu 80 pasien atau $76,9 \%$ dan nilai $\mathrm{p}=0,013$ $(p<0,05)$. Pasien PAD dengan gambaran gelombang bifasik di arteri poplitea mempunyai faktor risiko berupa hipertensi 59 pasien (75,6\%), hiperlipidemia 65 pasien $(76,5 \%)$, diabetes melitus 65 pasien $(76,5 \%)$ tetapi tidak bermakna secara statistik.

Pada (tabel 7), tampak pada arteri tibialis posterior terdapat gambaran gelombang monofasik pada 57 pasien $(54,8 \%)$ dengan usia diatas 45 tahun yang secara statistik bermakna dengan nilai $\mathrm{p}=$ $0,033$ ( $\mathrm{p}<0,05)$. Sedangkan pada faktorfaktor risiko yang lain tidak terdapat perbedaan dari segi jumlah pasien dan 


\section{ARTIKEL PENELITIAN}

presentasenya dan juga tidak terdapat hubungan signifikan antara perubahan gambaran gelombang DUS dengan faktorfaktor risiko. Pada tabel 8 tampak pada arteri dorsalis pedis gambaran gelombang monofasik lebih dominan pada 89 pasien $(85,6 \%)$ dengan nilai $\mathrm{p}=0,026$ pada pasien PAD di atas usia 45 tahun. Juga tampak peningkatan gambaran gelombang monofasik dengan hipertensi 63 pasien $(80,8 \%)$, hiperlipidemia 73 pasien $(85,9 \%)$ dan diabetes melitus 69 pasien $(81,2 \%)$ tetapi secara statistik tidak menunjukkan hubungan signifikan antara perubahan gelombang DUS dengan faktor-faktor risiko tersebut.

\section{Diskusi}

\section{Karakteristik faktor-faktor risiko pada pasien PAD}

Pada pasien PAD ditemukan usia median adalah 59 tahun. Hal ini sesuai dengan guideline PAD tahun 2016, dimana usia tua merupakan faktor risiko PAD. ${ }^{9}$ Berdasarkan jenis kelamin tidak ada perbedaan perbandingan antara laki-laki dan perempuan yaitu pada laki-laki terdapat 60 pasien atau 50,4\% sedangkan untuk perempuan sebanyak 59 pasien atau $49,8 \%$. Perbandingan antara perempuan : laki-laki adalah 1:1. Hal ini sesuai dengan penelitian
Kunihiro M dkk (2019) yang menyatakan perempuan memiliki risiko PAD yang sama dengan laki - laki baik berdasarkan kelompok ras / etnisnya. ${ }^{10}$ Secara karakteristik pasien merokok sebanyak 53,8\%. Jumlah pasien dengan hipertensi, peningkatan LDL darah dan diabetes melitus dengan PAD mempunyai presentase tinggi yaitu $65,5 \%, 71,4 \%$ dan $71,4 \%$ masing-masing. Faktor-faktor risiko tersebut meningkatkan kejadian PAD lebih besar sesuai dengan alur patogenesis atherosklerosis. Sedangkan pasien dengan riwayat $\mathrm{CAD}$ dan CVD mempunyai persentase dibawah 50\%. Hasil diatas konsisten berdasar beberapa studi sebelumnya. ${ }^{6,10,11,12}$

\section{Hubungan antara ABI dan faktor-}

\section{faktor risiko pada pasien PAD}

Berdasarkan karakteristik nilai ABI pada pasien PAD didapatkan rerata sebesar 0,7 dengan nilai terendah adalah 0.4 terdapat pada satu pasien dan tertinggi adalah 0,9. Data ini sesuai dengan kriteria diagnosis PAD berdasarkan ABI, bahwa penilaian awal PAD adalah dengan pemeriksaan $\mathrm{ABI} \leq 0,9 .^{2,5,6}$.

Pada penelitian ini ditemukan bahwa dengan meningkatnya usia $\geq 45$ th maka juga terjadi penurunan nilai $\mathrm{ABI} \leq 0,9$ dan 


\section{ARTIKEL PENELITIAN}

secara statistik terdapat hubungan signifikan dengan nilai $\mathrm{p}<0,05$. hal ini sesuai dengan berbagai penelitian sebelumnya yang menyatakan bahwa usia tua merupakan populasi dengan risiko tinggi menderita PAD. ${ }^{2,3,10}$ Peningkatan LDL darah juga mempunyai hubungan signifikan dengan penurunan nilai $\mathrm{ABI}$ $\leq 0,9$ dengan nilai $\mathrm{p}<0,05$ dan banyaknya pasien dengan peningkatan kadar LDL darah yang mempunyai ABI yang lebih rendah. Hal ini sesuai dengan penelitian kohort Kunihiro M (2019), riwayat penyakit jantung koroner, stroke dan faktor risiko tradisional (merokok, dislipidemia) memiliki angka prevalensi yang tinggi pada PAD. ${ }^{10}$

Pada faktor risiko diabetes melitus juga ditemukan hubungan signifikan dengan penurunan nilai $A B I$ yaitu $\mathrm{p}<0,05$ dan pasien PAD yang juga mempunyai diabetes terdapat nilai $\mathrm{ABI}$ yang lebih rendah. Hal ini sesuai dengan penelitian L. Potier dkk (2011) yang menyatakan bahwa pengukuran $\mathrm{ABI}$ adalah metode yang mudah dan terbukti efisien dalam mendiagnosis PAD dengan faktor risiko kardiovaskular dan diabetes. ${ }^{6}, 13$ Insidensi PAD pada diabetes 2 sampai 4 kali lipat lebih tinggi. ${ }^{14}$ Pasien diabetes dengan PAD seringkali terjadi sumbatan pada infrapopliteal dan adanya kalsifikasi vaskular. ${ }^{13}$ PAD pada diabetes berbeda dengan PAD yang disebabkan oleh rokok. Arteriopati pada pasien diabetes meliputi arteri-arteri distal lebih banyak daripada di proksimal. Pembuluh darah yang sering terkena adalah arteri poplitea, trunkus anterior tibioperoneal, tibialis posterior dan dorsalis pedis. ${ }^{13}$

\section{Hubungan antara Spektrum}

\section{Gelombang DUS dan faktor-faktor} risiko pada pasien PAD

Dari 119 pasien PAD didapatkan hasil perubahan gelombang DUS dari trifasik ke monofasik sesuai dengan urutan segmen arteri yaitu dari arteri femoralis, arteri poplitea, arteri tibialis posterior dan arteri dorsalis pedis. Gambaran didukung oleh penelitian Samia, dkk (2018), DUS memperlihatkan gambaran vaskular dan kecepatan aliran dan merupakan metode yang akurat untuk menentukan lokasi dan derajat keparahan PAD pada ekstremitas bawah dengan sensitivitas dan spesifitas diatas 90\%. Verim dkk (2013) menyatakan sensitivitas DUS menurun pada bagian distal yaitu di arteri tibialis posterior dan arteri dorsalis pedis pada suatu penelitian yang mengevaluasi 24 pasien dan 213 segmen arteri. ${ }^{15}$ Bergamini dkk meneliti 404 segmen arteri dan menemukan 86\% 


\section{ARTIKEL PENELITIAN}

ketepatan pada segmen arteri femoralis, $47 \%$ pada segmen arteri poplitea, dan $25 \%$ pada arteri tibalis posterior dan arteri dorsalis pedis. ${ }^{16}$

Pada segmen arteri femoralis hingga arteri dorsalis pedis terdapat hubungan signifikan antara peningkatan usia diatas 45 tahun dengan spektrum gelombang DUS yaitu nilai $\mathrm{p}<0,05$.

Meski tidak terdapat hubungan antara faktor-faktor risiko lain dengan gelombang DUS di arteri femoralis hingga arteri dorsalis pedis tetapi dari segi persentase perubahan gelombang DUS menjadi bifasik dan monofasik yang tinggi menunjukkan bahwa aliran darah ke perifer berkurang secara nyata. Pada arteri poplitea persentase gelombang bifasik pada semua faktor risiko diatas $50 \%$, Begitu pula di arteri tibialis posterior dimana faktor risiko seperti hipertensi, hiperlipidemia, riwayat CAD dan CVD memberi gambaran gelombang monofasik yang tinggi diatas $50 \%$ sedang untuk merokok terdapat gambaran bifasik diatas 51,6\%. Pada arteri dorsalis pedis bahkan seluruh faktor risiko menunjukkan persentase yang tinggi diatas $80 \%$ gelombang monofasik Hal ini memang secara statistik tidak signifikan tapi dari data klinis dapat dilihat bahwa faktor-faktor risiko menunjukkan peran penting dalam pembentukan atherosklerois dan terjadinya PAD.

\section{Hubungan antara ABI dan Spektrum}

\section{Gelombang DUS pada pasien PAD}

Pada segmen arteri femoralis hingga arteri dorsalis pedis dilakukan pengujian dengan Uji Mann Whitney dan didapatkan hasil yang signifikan antara penurunan nilai ABI $\leq 0,9$ dengan perubahan spektrum gelombang DUS dengan nilai $\mathrm{p}<0,05$. Hal ini menunjukkan aliran darah yang menurun dengan nilai ABI dibawah 0,9 dan juga dapat dideteksi dengan perubahan gelombang pada DUS. Hal ini sesuai dengan teori bahwa dengan semakin menyempitnya lumen arteri oleh karena berbagai sebab maka aliran ke distal lebih kecil hingga tampak pada spektrum gelombang DUS adanya perubahan gelombang yang pada ABI yang rendah dari bifasik menjadi monofasik. Makin rendah $\mathrm{ABI}$ maka makin kecil aliran darah ke distal dan tampak perubahan gelombang DUS kearah perburukan. ${ }^{15}$ Pada arteri femoralis didapatkan jumlah trifasik yang lebih banyak dibandingkan dengan gelombang bifasik tetapi masih tetap signifikan secara statistik antara hubungan penurunan nilai $\mathrm{ABI} \leq 0.9$ dengan spektrum gelombang DUS ini dikarenakan bahwa nilai $\mathrm{ABI}$ yang lebih rendah terdapat pada 


\section{ARTIKEL PENELITIAN}

arteri femoralis menunjukkan gambaran bifasik, dan makin rendah nilai ABI maka makin signifkan dengan perubahan gelombang DUS. ${ }^{15}$

Penelitian ini memiliki beberapa keterbatasan, yaitu jumlah sampel yang tidak cukup besar, subjek pada penelitian ini mungkin tidak bisa merepresentasikan populasi umum karena sampel diambil hanya dari satu Rumah Sakit Pendidikan, dan pengumpulan serta interpretasi dari hasil USG Doppler bergantung pada keahlian operator. Untuk memperoleh hasil yang lebih akurat dalam hal mendiagnosis dan mencegah PAD, harus direncanakan penelitian lebih lanjut dengan jumlah sampel yang jauh lebih besar.

\section{Kesimpulan}

Derajat keparahan PAD dapat ditentukan melalui nilai ABI dan DUS. Letak oklusi pada segmen arteri dapat diketahui dengan gelombang DUS. Penilaian ABI dan DUS memiliki hubungan positif yang signifikan terhadap faktor risiko usia, dm dan dislipidemia pada pasien PAD.

\section{Daftar Pustaka}

1. Nehler MR, Duval S, Diao L, Annex BH, Hiatt WR, Rogers K, et al. Epidemiology of peripheral arterial disease and critical limb ischemia in an insured national population. Journal of vascular surgery. 2014;60(3):686-95. e2.

2. Frank U, Nikol S, Belch J, Boc V, Brodmann M, Carpentier PH, et al. ESVM Guideline on peripheral arterial disease. Vasa. 2019;48(Suppl 102):1-79.

3. Shu J, Santulli G. Update on peripheral artery disease: epidemiology and evidence-based facts.

Atherosclerosis. 2018;275:379-81.

4. Chin JA, Wang EC, Kibbe MR. Evaluation of hyperspectral technology for assessing the presence and severity of peripheral artery disease. Journal of vascular surgery. 2011;54(6):1679-88.

5. Gupta A, Tyagi VK, Bansal N, Virmani S, Sirohi T. Comparison of ankle brachial pressure index to arterial doppler USG in the diagnosis of peripheral vascular 


\section{ARTIKEL PENELITIAN}

disease in diabetes mellitus.

International Journal of Advances

in Medicine. 2017;4(6):1562.

6. Marius R-A, Iliuta L, Guberna SM, Sinescu C. The role of anklebrachial index for predicting peripheral arterial disease. Maedica. 2014;9(3):295.

7. Deane C. Ultrasound in Peripheral Arterial Disease. EFSUMB Course Book on Ultrasound: Latimer Trend \& Company Ltd; 2012.

8. Natha B. Screening for peripheral arterial disease. SAMJ: South African Medical Journal. 2014;104(2):149-.

9. Morcos R, Louka B, Tseng A, Misra S, McBane R, Esser H, et al. The evolving treatment of peripheral arterial disease through guideline-directed recommendations. Journal of Clinical Medicine. 2018;7(1):9.

10. Matsushita K, Sang Y, Ning H, Ballew SH, Chow EK, Grams ME, et al. Lifetime Risk of LowerExtremity Peripheral Artery Disease Defined by Ankle-Brachial Index in the United States. Journal of the American Heart Association. 2019;8(18):e012177.
11. Ogata H, Kumata-Maeta C, Shishido K, Mizobuchi M, Yamamoto M, Koiwa $F$, et al. Detection of peripheral artery disease by duplex ultrasonography among hemodialysis patients. Clinical Journal of the American Society of Nephrology. 2010;5(12):2199-206.

12. Subramaniam T, Nang EEK, Lim $\mathrm{SC}, \mathrm{Wu} \mathrm{Y}$, Khoo CM, Lee J, et al. Distribution of ankle-brachial index and the risk factors of peripheral artery disease in a multiethnic Asian population. Vascular medicine. 2011;16(2):87-95.

13. Potier L, Abi Khalil C, Mohammedi $\mathrm{K}$, Roussel R. Use and utility of ankle brachial index in patients with diabetes. European Journal of Vascular and Endovascular Surgery. 2011;41(1):110-6.

14. Balletshofer $\mathrm{B}$, Ito $\mathrm{W}$, Lawall $\mathrm{H}$, Malyar N, Oberländer Y, Reimer P, et al. Position paper on the diagnosis and treatment of peripheral arterial disease (PAD) in people with diabetes mellitus. Experimental and Clinical Endocrinology \& Diabetes. 2019;127(S 01):S105-S13. 


\section{ARTIKEL PENELITIAN}

15. Verim S, Taşçı İ. Doppler ultrasonography in lower extremity peripheral arterial disease. Arch Turk Soc Cardiol. 2013;41(3):24855.

16. Bergamini TM, Tatum Jr CM, Marshall C, Hall-Disselkamp B, Richardson JD. Effect of multilevel sequential stenosis on lower extremity arterial duplex scanning. The American journal of surgery. 1995;169(6):564-6. 


\section{ARTIKEL PENELITIAN}

\section{Daftar Tabel}

Tabel 1. Karekteristik Spektrum Gelombang USG Doppler pada pasien PAD

\begin{tabular}{lccc}
\hline \multicolumn{1}{c}{ Variabel } & & $\mathrm{n}$ & $\%$ \\
\hline Gelombang A.Femoralis & Trifasik & 73 & $61,30 \%$ \\
& Bifasik & 46 & $38,70 \%$ \\
& Monofasik & 0 & $0 \%$ \\
Gelombang A..Poplitea & & & \\
& Trifasik & 28 & $23,50 \%$ \\
& Bifasik & 87 & $73,10 \%$ \\
& Monofasik & 4 & $3,40 \%$ \\
Gelombang A.Tibialis & & & \\
Posterior & Trifasik & 3 & $2,50 \%$ \\
& Bifasik & 56 & $47,10 \%$ \\
& Monofasik & 60 & $50,40 \%$ \\
Gelombang A.Dorsalis Pedis & Trifasik & 0 & $0 \%$ \\
& Bifasik & 21 & $17,60 \%$ \\
& Monofasik & 98 & $82,40 \%$ \\
\hline
\end{tabular}

Tabel 2. Karakteristik ABI dan Distribusi Usia pada pasien PAD

\begin{tabular}{ll}
\hline Variabel & Median ( Min - Max) \\
\hline Usia & $59(30-81)$ \\
ABI & $0.7(0,4-0,9)$ \\
\hline
\end{tabular}




\section{ARTIKEL PENELITIAN}

Tabel 3. Hubungan antara ABI dan Spektrum USG Doppler

\begin{tabular}{lcc}
\hline Variabel & ABI & $P$ \\
\cline { 2 - 3 } $\begin{array}{l}\text { A. Femoralis } \\
\text { Trifasik }\end{array}$ & $0,76(0,6-0,9)$ & \\
Bifasik & $0,6(0,4-0,9)$ & $<0,001$ \\
Monofasik & - & \\
& & \\
A. Poplitea & & \\
Trifasik & $0,8(0,6-0,9)$ & \\
Bifasik & $0,7(0,4-0,9)$ & \\
Monofasik & $0,6(0,6-0,6)$ & \\
&
\end{tabular}

A. Tibialis Posterior Trifasik

Bifasik

Monofasik

$0,8(0,7-0,9)$

$0,78(0,4-0,9)$

0,002

$0,7(0,5-0,9)$

A. Dorsalis Pedis

Trifasik

Bifasik

$0,8(0,6-0,9)$

Monofasik

$0,7(0,4-0,9)$ 


\section{ARTIKEL PENELITIAN}

Tabel 4. Hubungan antara ABI dan Faktor-faktor Risiko pada pasien PAD

\begin{tabular}{|c|c|c|c|}
\hline Variabel & & $\mathrm{ABI}$ & $\mathrm{p}$ \\
\hline \multirow[t]{2}{*}{ Usia } & $\geq 45$ th & $0,7(0,4-0,9)$ & \multirow{2}{*}{$<0,001$} \\
\hline & $\leq 45$ th & $0,8(0,6-0,9)$ & \\
\hline \multirow[t]{2}{*}{ Jenis Kelamin } & Laki-laki & $0,7(0,4-0,9)$ & \multirow{2}{*}{0,909} \\
\hline & Perempuan & $0,7(0,5-0,9)$ & \\
\hline \multirow[t]{2}{*}{ Merokok } & $\mathrm{Ya}$ & $0,7(0,4-0,9)$ & \multirow{2}{*}{0,734} \\
\hline & Tidak & $0,7(0,5-0,9)$ & \\
\hline \multirow[t]{2}{*}{ Hipertensi } & $\mathrm{Ya}$ & $0,69(0,4-0,9)$ & \multirow{2}{*}{0,169} \\
\hline & Tidak & $0,72(0,5-0,9)$ & \\
\hline \multirow[t]{2}{*}{ Hiperlipidemia } & $\mathrm{Ya}$ & $0,69(0,4-0,9)$ & \multirow{2}{*}{0,010} \\
\hline & Tidak & $0,74(0,6-0,9)$ & \\
\hline \multirow[t]{2}{*}{ Diabetes Melitus } & $\mathrm{Ya}$ & $0,69(0,4-0,87)$ & \multirow{2}{*}{0,037} \\
\hline & Tidak & $0,73(0,5-0,9)$ & \\
\hline \multirow[t]{2}{*}{ Riwayat CAD } & $\mathrm{Ya}$ & $0,69(0,4-0,87)$ & \multirow{2}{*}{0,753} \\
\hline & Tidak & $0,71(0,5-0,9)$ & \\
\hline \multirow[t]{2}{*}{ Riwayat CVD } & $\mathrm{Ya}$ & $0,68(0,4-0,86)$ & \multirow{2}{*}{0,234} \\
\hline & Tidak & $0,71(0,5-0,9)$ & \\
\hline
\end{tabular}




\section{ARTIKEL PENELITIAN}

Tabel 5. Hubungan antara Spektrum USG Doppler Arteri Femoralis dengan Faktorfaktor risiko

\begin{tabular}{|c|c|c|c|c|c|}
\hline \multirow{2}{*}{ Variabel } & \multicolumn{4}{|c|}{ Arteri Femoralis } & \multirow{2}{*}{$\mathrm{P}$} \\
\hline & & Trifasik & Bifasik & Monofasik & \\
\hline \multirow[t]{2}{*}{ Usia } & $\geq 45$ th & $59(56,7 \%)$ & $45(43,3 \%)$ & $0(0 \%)$ & \multirow{2}{*}{0,006} \\
\hline & $\leq 45$ th & $14(93,3 \%)$ & $1(6,7 \%)$ & $0(0 \%)$ & \\
\hline \multirow[t]{2}{*}{ Jenis Kelamin } & Laki-laki & $38(63,3 \%)$ & $22(36,7 \%)$ & $0(0 \%)$ & \multirow{2}{*}{0,653} \\
\hline & Perempuan & $35(59,3 \%)$ & $24(40,7 \%)$ & $0(0 \%)$ & \\
\hline \multirow[t]{2}{*}{ Merokok } & $\mathrm{Ya}$ & $39(60,9 \%)$ & $25(39,1 \%)$ & $0(0 \%)$ & \multirow{2}{*}{0,992} \\
\hline & Tidak & $34(61,8 \%)$ & $21(38,2 \%)$ & $0(0 \%)$ & \\
\hline \multirow[t]{2}{*}{ Hipertensi } & $\mathrm{Ya}$ & $45(57,7 \%)$ & $33(42,3 \%)$ & $0(0 \%)$ & \multirow{2}{*}{0,259} \\
\hline & Tidak & $28(68,3 \%)$ & $13(31,7 \%)$ & $0(0 \%)$ & \\
\hline \multirow[t]{2}{*}{ Hiperlipidemia } & Ya & $51(60 \%)$ & $34(40 \%)$ & $0(0 \%)$ & \multirow{2}{*}{0,634} \\
\hline & Tidak & $22(64,7 \%)$ & $12(35,3 \%)$ & $0(0 \%)$ & \\
\hline \multirow[t]{2}{*}{ Diabetes Melitus } & Ya & $49(57,6 \%)$ & $36(42,4 \%)$ & $0(0 \%)$ & \multirow{2}{*}{0,190} \\
\hline & Tidak & $24(70,6 \%)$ & $10(29,4 \%)$ & $0(0 \%)$ & \\
\hline \multirow[t]{2}{*}{ Riwayat CAD } & $\mathrm{Ya}$ & $26(61,9 \%)$ & $16(38,1 \%)$ & $0(0 \%)$ & \multirow{2}{*}{0,926} \\
\hline & Tidak & $47(61 \%)$ & $30(39 \%)$ & $0(0 \%)$ & \\
\hline \multirow[t]{2}{*}{ Riwayat CVD } & $\mathrm{Ya}$ & $18(60 \%)$ & $12(40 \%)$ & $0(0 \%)$ & \multirow{2}{*}{0,861} \\
\hline & Tidak & $55(61,8 \%)$ & $34(38,2 \%)$ & $0(0 \%)$ & \\
\hline
\end{tabular}




\section{ARTIKEL PENELITIAN}

Tabel 6. Hubungan antara Spektrum USG Doppler Arteri Poplitea dengan Faktor-faktor risiko

\begin{tabular}{|c|c|c|c|c|c|}
\hline \multirow{2}{*}{ Variabel } & \multicolumn{4}{|c|}{ Arteri Poplitea } & \multirow{2}{*}{$\mathrm{P}$} \\
\hline & & Trifasik & Bifasik & Monofasik & \\
\hline \multirow[t]{2}{*}{ Usia } & $\geq 45$ th & $20(19,2 \%)$ & $80(76,9 \%)$ & $4(3,8 \%)$ & 0,013 \\
\hline & $\leq 45$ th & $8(53,3 \%)$ & $7(46,7 \%)$ & $0(0 \%)$ & \\
\hline \multirow[t]{2}{*}{ Jenis Kelamin } & Laki-laki & $17(28,3 \%)$ & $42(70 \%)$ & $1(1,7 \%)$ & 0,304 \\
\hline & Perempuan & $11(18,6 \%)$ & $45(76,3 \%)$ & $3(5,1 \%)$ & \\
\hline \multirow[t]{2}{*}{ Merokok } & Ya & $18(28,1 \%)$ & $45(70,3 \%)$ & $1(1,6 \%)$ & 0,356 \\
\hline & Tidak & $10(18,2 \%)$ & $42(76,4 \%)$ & $3(5,5 \%)$ & \\
\hline \multirow[t]{2}{*}{ Hipertensi } & Ya & $17(21,8 \%)$ & $59(75,6 \%)$ & $2(2,6 \%)$ & 0,633 \\
\hline & Tidak & $11(26,8 \%)$ & $28(68,3 \%)$ & $2(4,9 \%)$ & \\
\hline \multirow[t]{2}{*}{ Hiperlipidemia } & Ya & $17(20 \%)$ & $65(76,5 \%)$ & $3(3,5 \%)$ & 0,357 \\
\hline & Tidak & $11(32,4 \%)$ & $22(64,7 \%)$ & $1(2,9 \%)$ & \\
\hline \multirow[t]{2}{*}{ Diabetes Melitus } & Ya & $17(20 \%)$ & $65(76,5 \%)$ & $3(3,5 \%)$ & 0,357 \\
\hline & Tidak & $11(32,4 \%)$ & $22(64,7 \%)$ & $1(2,9 \%)$ & \\
\hline \multirow[t]{2}{*}{ Riwayat CAD } & Ya & $8(19 \%)$ & $33(78,6 \%)$ & $1(2,4 \%)$ & 0,605 \\
\hline & Tidak & $20(26 \%)$ & $54(70,1 \%)$ & $3(3,9 \%)$ & \\
\hline \multirow[t]{2}{*}{ Riwayat CVD } & Ya & $4(27 \%)$ & $26(86,7 \%)$ & $0(0 \%)$ & 0,137 \\
\hline & Tidak & $24(27 \%)$ & $61(68,5 \%)$ & $4(4,5 \%)$ & \\
\hline
\end{tabular}




\section{ARTIKEL PENELITIAN}

Tabel 7. Hubungan antara Spektrum USG Doppler Arteri Tibialis Posterior dengan

Faktor-faktor risiko

\begin{tabular}{|c|c|c|c|c|c|}
\hline \multirow{2}{*}{ Variabel } & \multicolumn{4}{|c|}{ Arteri Tibialis Posterior } & \multirow{2}{*}{$\mathrm{P}$} \\
\hline & & Trifasik & Bifasik & Monofasik & \\
\hline \multirow[t]{2}{*}{ Usia } & $\geq 45$ th & $2(1,9 \%)$ & $45(43,3 \%)$ & $57(54,8 \%)$ & \multirow{2}{*}{0,033} \\
\hline & $\leq 45$ th & $1(6,7 \%)$ & $11(73,3 \%)$ & $3(20 \%)$ & \\
\hline \multirow[t]{2}{*}{ Jenis Kelamin } & Laki-laki & $2(3,3 \%)$ & $30(50 \%)$ & $28(46,7 \%)$ & \multirow{2}{*}{0,645} \\
\hline & Perempuan & $1(1,7 \%)$ & $26(44,1 \%)$ & $32(54,2 \%)$ & \\
\hline \multirow[t]{2}{*}{ Merokok } & $\mathrm{Ya}$ & $2(3,1 \%)$ & $35(51,6 \%)$ & $29(45,3 \%)$ & \multirow{2}{*}{0,469} \\
\hline & Tidak & $1(1,8 \%)$ & $23(41,8 \%)$ & $31(56,4 \%)$ & \\
\hline \multirow[t]{2}{*}{ Hipertensi } & $\mathrm{Ya}$ & $1(1,3 \%)$ & $37(47,4 \%)$ & $40(55,3 \%)$ & \multirow{2}{*}{0,492} \\
\hline & Tidak & $2(4,9 \%)$ & $19(46,3 \%)$ & $20(48,8 \%)$ & \\
\hline \multirow[t]{2}{*}{ Hiperlipidemia } & $\mathrm{Ya}$ & $2(2,4 \%)$ & $36(42,4 \%)$ & $47(55,3 \%)$ & \multirow{2}{*}{0,242} \\
\hline & Tidak & $1(2,9 \%)$ & $20(58,8 \%)$ & $13(38,2 \%)$ & \\
\hline \multirow[t]{2}{*}{ Diabetes Melitus } & $\mathrm{Ya}$ & $2(2,4 \%)$ & $42(49,4 \%)$ & $41(48,2 \%)$ & \multirow{2}{*}{0,717} \\
\hline & Tidak & $1(2,9 \%)$ & $14(41,2 \%)$ & $19(55,9 \%)$ & \\
\hline \multirow[t]{2}{*}{ Riwayat CAD } & $\mathrm{Ya}$ & $2(4,8 \%)$ & $16(38,1 \%)$ & $24(57,1 \%)$ & \multirow{2}{*}{0,225} \\
\hline & Tidak & $1(1,3 \%)$ & $40(51,9 \%)$ & $36(46,8 \%)$ & \\
\hline \multirow[t]{2}{*}{ Riwayat CVD } & Ya & $0(0 \%)$ & $14(46,7 \%)$ & $16(53,3 \%)$ & \multirow{2}{*}{0,583} \\
\hline & Tidak & $3(3,4 \%)$ & $42(47,2 \%)$ & $44(49,4 \%)$ & \\
\hline
\end{tabular}




\section{ARTIKEL PENELITIAN}

Tabel 8. Hubungan antara Spektrum USG Doppler Arteri Dorsalis Pedis dengan Faktorfaktor risiko

\begin{tabular}{|c|c|c|c|c|c|}
\hline \multirow{2}{*}{ Variabel } & \multicolumn{4}{|c|}{ Arteri Dorsalis Pedis } & \multirow{2}{*}{$\mathrm{P}$} \\
\hline & & Trifasik & Bifasik & Monofasik & \\
\hline \multirow[t]{2}{*}{ Usia } & $\geq 45$ th & $0(0 \%)$ & $89(85,6 \%)$ & $57(54,8 \%)$ & \multirow{2}{*}{0,026} \\
\hline & $\leq 45$ th & $0(0 \%)$ & $9(60 \%)$ & $3(20 \%)$ & \\
\hline \multirow[t]{2}{*}{ Jenis Kelamin } & Laki-laki & $0(0 \%)$ & $11(18,3 \%)$ & $49(81,7 \%)$ & \multirow{2}{*}{0,843} \\
\hline & Perempuan & $0(0 \%)$ & $10(16,9 \%)$ & $49(83,1 \%)$ & \\
\hline \multirow[t]{2}{*}{ Merokok } & Ya & $0(0 \%)$ & $12(18,8 \%)$ & $52(81,3 \%)$ & \multirow{2}{*}{0,743} \\
\hline & Tidak & $0(0 \%)$ & $9(16,4 \%)$ & $46(83,6 \%)$ & \\
\hline \multirow[t]{2}{*}{ Hipertensi } & Ya & $0(0 \%)$ & $15(19,2 \%)$ & $63(80,8 \%)$ & \multirow{2}{*}{0,532} \\
\hline & Tidak & $0(0 \%)$ & $6(14,6 \%)$ & $35(85,4 \%)$ & \\
\hline \multirow[t]{2}{*}{ Hiperlipidemia } & Ya & $0(0 \%)$ & $12(14,1 \%)$ & $73(85,9 \%)$ & \multirow{2}{*}{0,110} \\
\hline & Tidak & $0(0 \%)$ & $9(26,5 \%)$ & $25(73,5 \%)$ & \\
\hline \multirow[t]{2}{*}{ Diabetes Melitus } & Ya & $0(0 \%)$ & $16(18,8 \%)$ & $69(81,2 \%)$ & \multirow{2}{*}{0,595} \\
\hline & Tidak & $0(0 \%)$ & $5(14,7 \%)$ & $29(85,3 \%)$ & \\
\hline \multirow[t]{2}{*}{ Riwayat CAD } & Ya & $0(0 \%)$ & $6(14,3 \%)$ & $36(85,7 \%)$ & \multirow{2}{*}{0,477} \\
\hline & Tidak & $0(0 \%)$ & $15(19,5 \%)$ & $62(80,5 \%)$ & \\
\hline \multirow[t]{2}{*}{ Riwayat CVD } & Ya & $0(0 \%)$ & $2(6,7 \%)$ & $28(93,3 \%)$ & \multirow{2}{*}{0,068} \\
\hline & Tidak & $0(0 \%)$ & $19(21,3 \%)$ & $70(78,7 \%)$ & \\
\hline
\end{tabular}

